\title{
Preliminary analysis of the forest health state based on multispectral images acquired by Unmanned Aerial Vehicle
}

\author{
Pawet Czapski ${ }^{1}$,Mariusz Kacprzak ${ }^{1}$, Jan Kotlarz ${ }^{1}$, Karol Mrowiec ${ }^{1}$, Katarzyna Kubiak ${ }^{2}$, \\ Miłosz Tkaczyk \\ ${ }^{1}$ Institute of Aviation, Center of Space Technologies, al. Krakowska 110/114, 02-256 Warszawa, Poland \\ ${ }^{2}$ Forest Research Institute, Department of Forest Protection, Sękocin Stary, Braci Leśnej 3, 05-090 Raszyn, Poland, \\ phone: 48 227150823, e-mail: M.Tkaczyk@ibles.waw.pl
}

\begin{abstract}
The main purpose of this publication is to present the current progress of the work associated with the use of a lightweight unmanned platforms for various environmental studies. Current development in information technology, electronics and sensors miniaturisation allows mounting multispectral cameras and scanners on unmanned aerial vehicle (UAV) that could only be used on board aircraft and satellites. Remote Sensing Division in the Institute of Aviation carries out innovative researches using multisensory platform and lightweight unmanned vehicle to evaluate the health state of forests in Wielkopolska province. In this paper, applicability of multispectral images analysis acquired several times during the growing season from low altitude (up to $800 \mathrm{~m}$ ) is presented. We present remote sensing indicators computed by our software and common methods for assessing state of trees health. The correctness of applied methods is verified using analysis of satellite scenes acquired by Landsat 8 OLI instrument (Operational Land Imager).
\end{abstract}

\section{KeY WORDS}

remote sensing, UAV, UAS, satellite images, vegetation analysis, remote sensing indicators, multispectral images

\section{INTRODUCTION}

Optical remote sensing techniques are used for various environmental studies for more than 40 years. The very first analysis were conducted based on satellite images for very large areas (tens of thousands of square kilometers), that is, macro-scale studies. In that time, Earth remote sensing data were obtained by environmental satellites, in particular, by the first generations of Land- sat satellites. Multispectral scanner (MSS) recorded four spectral ranges with a spatial resolution of about $79 \mathrm{~m}$, that is, green $(0.5-0.6 \mu \mathrm{m})$, red $(0.6-0.7 \mu \mathrm{m})$, NIR1 $(0.7-0.8 \mu \mathrm{m})$ and NIR2 $(0.8-1.1 \mu \mathrm{m})$ band (Ciołkosz, Kęsik 1989). Each object on the Earth reflects electromagnetic radiation that originates from various sources, and the intensity of the reflection is characteristic for a given spectral range. Passive remote sensing methods used for environmental studies use recording of elec- 
tromagnetic radiation that is emitted by the sun passed through the atmosphere and is reflected from the surface of the planet (the analysed object) (Bernasik 2003). Using recorded images in a number of spectral bands allows performing quantitative and qualitative analysis. The distribution of reflectance of a given object of interest that depends on the length of the electromagnetic wave is called the spectral characteristics. Using the reference data stored in dedicated spectral libraries, various works can be carried out, for example, land cover classification (Osińska-Skotak 2007). Each pixel of the registered image represents the actual object in the investigated area. Ground sample distance (GSD) determines the accuracy of the analyses. It can be assumed that a successful detection and interpretation of the object is possible when the investigated object will be registered at least in three pixels (Białołusz, Skłodowski 1999). Radiometric pixel value is the basis for calculation of remote sensing indices, which in turn are used for remote environmental assessment. The accuracy of the analysis decreases significantly when size of the GSD is greater than the physical size of the analysed object. Then, radiometric value is influenced by elements in its very vicinity, that is, background that interferes with a proper measurement of reflectance. Therefore, this is of great importance to select and check the possibility of obtaining a suitable source material at the stage of planning environmental analysis. Initially, the research related to optical remote sensing was carried out on the basis of satellite scenes, with time also began to build metric aerial cameras operating in multiple spectral channels. Initially, researches related to optical remote sensing were carried out using satellite scenes, and the next step was using metric aerial cameras operating in multiple spectral channels. Currently, technology provide us with more possibilities for acquiring multispectral images such as rapidly developing unmanned aircraft systems (UAS). Initially, the so-called drones were used for image acquisition of various objects for military purpose and later in private and commercial applications. Along with the popularisation of UAS, remotely controlled system became an interesting solutions for delivering works on photogrammetry and remote sensing (Kurczyński 2014). Digital development in photography and increasing market needs opened possibility to small and lightweight non-metric multispectral cameras compatible with lightweight unmanned platforms. In the Remote Sensing Division of
Institute of Aviation, light (4 kg) multispectral camera was designed and built (Czapski et al. 2014) and is used in research on the evaluation of the health state of sessile oak stands. Ground pixel of images is relatively small $(<0.25 \mathrm{~m})$, thus calculated remote sensing indices can be assigned to particular investigated trees. Assessment of the health of the forest is based on local measurements, which are then referenced to the whole investigated area.

\section{ACQUISITION OF MULTISPECTRAL IMAGES USING Unmanned Aerial Vehicle}

Interests on employing UAS in the field of photogrammetry is increasing. Whilst maintaining associated with acquisition and processing standards in the process of image acquisition by non-metric digital cameras, and using appropriate software, it is possible to obtain satisfactory results. First of all, image must be sharp enough, autofocus must be turned off and exposure time should be as short as possible. If exposure time is too long, images will be blurred, so their quality might be not enough for further processing. The exposure must be set to manual mode, aperture, exposure time and sensitivity of the sensor should be the same for each photo. It is of great importance that a remotely controlled platform during image acquisition should move with nearly constant linear velocity, and angular velocity around all axes should be 0 and attitude as parallel to ground as possible. Considerably, low mass of unmanned platforms makes them very susceptible to wind; therefore, images should be acquired during light winds condition and were not deflected from the vertical by more than 5 degree. Owing to the small terrain coverage of a single scene compared to size of a typical buildings covering some area (buildings, water reservoirs, forests) mosaicking lines often are run through areas where it is not possible to properly hide the appropriate mosaicking lines (Kurczyński 2006, Ciołkosz, Białousz 2008). Despite some technical barriers associated with processing non-metric images, it is reasonable to use unmanned aerial vehicle (UAV) for acquisition of source material for periodically conducted research of small area of up to $2 \mathrm{~km}^{2}$. During a single flight, it is possible to acquire material of an area of approximately 50 ha (up to 110 ha). During a project that is carried out by the Institute of Aviation, images of three investigated areas are acquired (Fig. 1). 


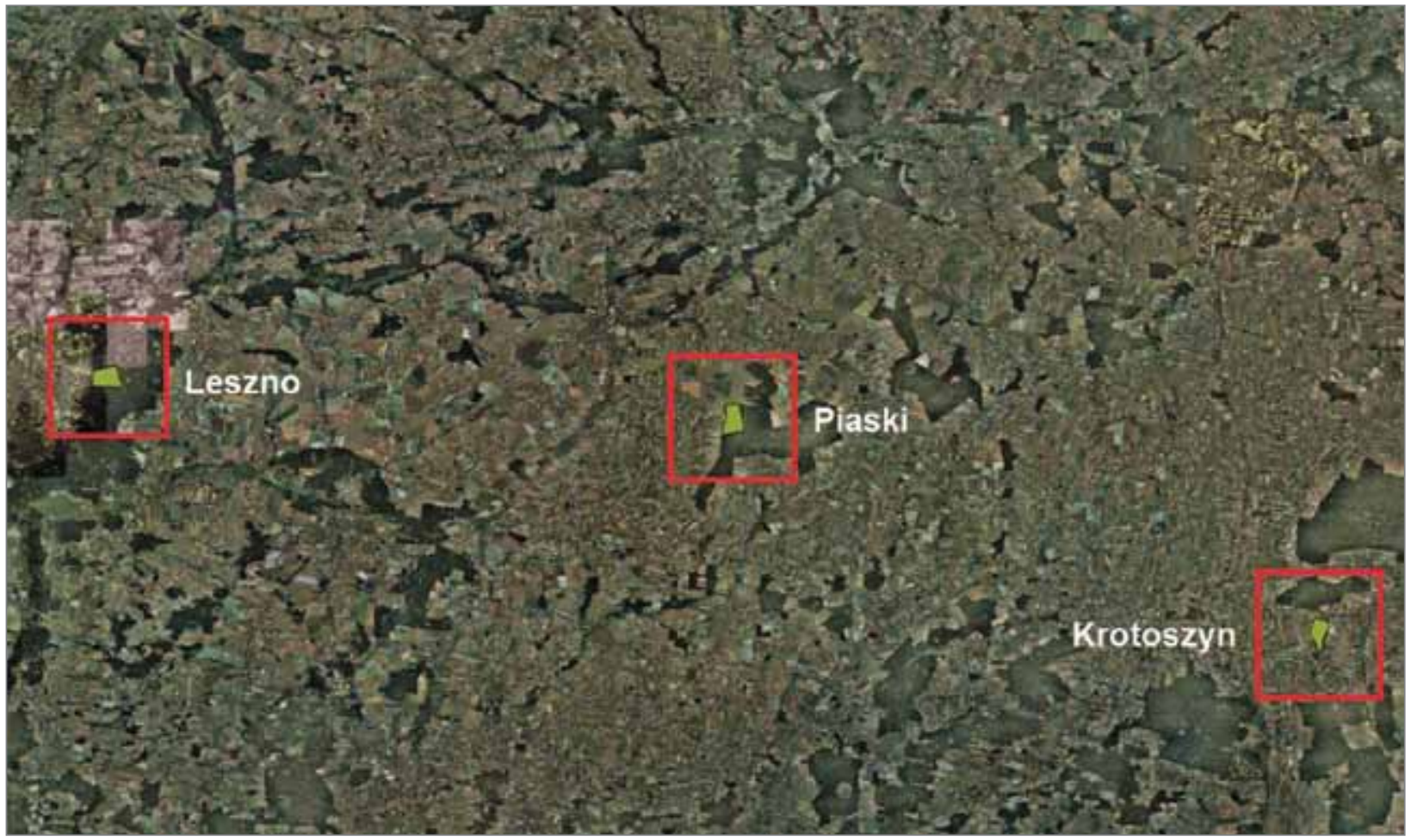

Figure 1. Location of three investigated areas in our project

The main focus of this project is put on developing and introducing the novel objective evaluation methods into practice in forest. Images collected during the project are characterised by a relatively small ground pixel, where size of a single pixel does not exceed $25 \mathrm{~cm}$ (for flight below 800 meters). In Table 1, parameters of acquired images against flight level of unmanned platform are presented.

Table 1. Parameters of images depending on the flight level

\begin{tabular}{|c|c|c|c|c|}
\hline \multirow{2}{*}{$\begin{array}{c}\text { Flight } \\
\text { level } \\
{[\mathrm{m}]}\end{array}$} & \multicolumn{2}{|c|}{$\begin{array}{c}\text { Coverage } \\
\text { of a single pixel }\end{array}$} & \multirow{2}{*}{$\begin{array}{c}\text { Area } \\
\text { of image } \\
{\left[\mathrm{m}^{2}\right]}\end{array}$} & \multirow{2}{*}{$\begin{array}{c}\text { Ground } \\
\text { sampling } \\
\text { distance } \\
\text { (GSD) } \\
{[\mathrm{cm}]}\end{array}$} \\
\hline & $\begin{array}{l}\text { In direction } \\
\text { of flight } \\
{[\mathrm{m}]}\end{array}$ & $\begin{array}{c}\text { Crosswise } \\
\text { to flight } \\
\text { line [m] }\end{array}$ & & \\
\hline 200 & 46.35 & 69.18 & $3,206.31$ & 5.8 \\
\hline 400 & 92.70 & 138.36 & $12,825.23$ & 11.5 \\
\hline 600 & 139.05 & 207.53 & $28,856.77$ & 17.3 \\
\hline 800 & 185.40 & 276.71 & $51,300.93$ & 23.1 \\
\hline
\end{tabular}

Images obtained by unmanned platform are competitive to those obtained using satellites and manned aircraft. Ground pixel size of satellite scenes has reached the submeter accuracy; however, temporal resolution for images acquired by unmanned platform is still much better.

\section{ANALYsis of COllected IMAGe dATA AND PRELIMINARY RESULTS OF EXPERIMENTAL WORK}

A proper evaluation of images taken by unmanned platform and subsequent interpretation can be carried out only by specialists who are aware of the restrictions resulting from the application of innovative methods of obtaining images. Methods and techniques used in standard aerial photogrammetry can only be used as a general assessment, not the sole determinant criterion used to evaluate the collected material. In addition, dedicated software that is able to process huge amount of data sets must be used to process images taken by an UAV. Single image is smaller than an aerial image, but their quantity might be in the range of thousands. In the alignment process of such a block of images, there is a huge number of remote sensing equations 
and other unknowns. It is often not possible to perform photogrammetric processing of the whole source data, so simplified methods and dedicated software for image processing acquired by unmanned aircraft are used. The Remote Sensing Division of Institute of Aviation carries out work on the development of software that will allow for geometric matching series of images and computing remote sensing indices of different objects (e.g. selected trees that are investigated). Owing to the lack of sufficiently accurate land cover model, it is impossible to perform orthorectification on images, create orthophotomaps and compute remote sensing indices for the entire investigated area. Works are carried out on single images that are matched based on characteristic points, then the test object is shown and its approximate radius in pixel units is given). The result of processing are the relevant remote sensing indices calculated for the central point and the entire investigated area.

Analysis and comparison of various remote sensing indices, indices collected in situ by a forester and data acquired from the macro-scale using Landsat 8, allows for a complete and comprehensive assessment of the forest health state. Remote sensing indices are used to assess the quality of the studied phenomenon. In the case of vegetation studies, relevant vegetation indices that allow for a qualitative estimation of the health of flora covering the surface of the earth are used. Multispectral camera designed in the Institute of Aviation allows acquiring images simultaneously in six spectral bands, and 24 filters in the range of 400-1000 [nm] can be used. On the basis of recorded image data, the following remote sensing indices are computed:

- NDVI: normalized vegetation index, which is widely used in all kinds of vegetation studies. This index is used to estimate plant vigor and biomass. Long-term NDVI monitoring allows providing different forecast, for example, crop yields (Ciołkosz, Białousz 2008). Repeated NDVI measurements allow capturing adverse trends. In Table 2, NDVI measured in various vegetation cycles are presented. With this indicator, it is possible to identify the different phases of plant development.

- NDWI (normalized difference water index): normalised rate of water based on the values of reflectance in the range of red and near infrared. This index is very sensitive to changes in water content within the structure of plants and also includes the effect of soil moisture (Czapski et al. 2014). Knowledge of the water balance is very important in the assessment of habitat conditions and phases of plant development. The results obtained with photos acquired with UAV are highly correlated with results generated with Landsat images use.

Table 2. NDVI values for selected trees in 2014 or 2015

\begin{tabular}{|c|c|c|c|c|c|c|c|}
\hline \multirow{3}{*}{\multicolumn{2}{|c|}{$\begin{array}{l}\text { Investigated } \\
\text { area ID, tree ID }\end{array}$}} & \multicolumn{6}{|c|}{ NDVI [\%] } \\
\hline & & \multicolumn{3}{|c|}{2013} & \multicolumn{3}{|c|}{2014} \\
\hline & & \multirow{2}{*}{$\begin{array}{l}\frac{\lambda}{\Xi} \\
X\end{array}$} & \multirow{2}{*}{$\begin{array}{l}\dot{0} \\
\frac{0}{0} \\
\stackrel{0}{0} \\
\end{array}$} & \multirow{2}{*}{ 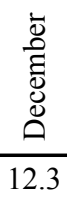 } & \multirow{2}{*}{$\begin{array}{l}\overline{\bar{Z}} \\
53.5\end{array}$} & \multirow{2}{*}{$\frac{\stackrel{\Xi}{\Xi}}{61.0}$} & \multirow{2}{*}{$\frac{\gtrsim}{50.6}$} \\
\hline \multirow{4}{*}{$\begin{array}{l}\text { Karczma } \\
\text { Borowa }\end{array}$} & KB_7 & & & & & & \\
\hline & KB_9 & $X$ & $X$ & 17.2 & 40.3 & 46.5 & 56.0 \\
\hline & KB_36 & $X$ & $X$ & 19.2 & 44.7 & 57.9 & 58.7 \\
\hline & KB_60 & $X$ & $\mathrm{X}$ & 7.8 & 44.0 & 47.7 & 57.5 \\
\hline \multirow{3}{*}{$\begin{array}{l}\text { Kroto- } \\
\text { szyn }\end{array}$} & KR_13 & 39.2 & 30.5 & 11.9 & 40.4 & 47.1 & 48.8 \\
\hline & KR_36 & 41.5 & 33.2 & 23.2 & 42.8 & 46.2 & 56.7 \\
\hline & KR_40 & 33.9 & 40.3 & 22.0 & 49.6 & 49.6 & 48.8 \\
\hline \multirow{3}{*}{ Piaski } & PI_9 & $\mathrm{X}$ & 38.2 & 20.1 & 46.2 & 56.2 & 43.4 \\
\hline & PI_20 & $X$ & 38.7 & 17.9 & 58.7 & 45.2 & 54.8 \\
\hline & \begin{tabular}{|l|} 
PI_84 \\
\end{tabular} & $\mathrm{X}$ & 49.2 & 11.1 & 57.5 & 53.2 & 48.3 \\
\hline
\end{tabular}

NDWI and NDVI are calculated based on the images with small GSD; their values are compared with the data in the macro-scale, that is, indices calculated from satellite scenes. In addition, measurements are complemented by indicators calculated based on the satellite scenes (OLI instrument). They are directly linked to the content of water in the investigated area. Water relations and knowledge of the terrain is of great importance to correctly assess environmental conditions.

- NDII (normalized difference infrared index): index that is very sensitive to changes in the amount of water in the vegetation. Value of this index increases with water content (Hardisky et al. 1983).

- MSI (moisture stress index): vegetation water stress that occurs when the air temperature is higher than the temperature of the substrate $\left(\right.$ MSI $\left.=\frac{\text { BAND6 }}{\text { BAND5 }}\right)$ (Niedzielko et al. 2012). 
Remote sensing indices are compared with groundbased observations. Investigated trees belong to the same species and were planted at the same time; therefore, associated differences of social class tree position are negligible. In addition, forester assessed the vitality of a tree using the method proposed by Andreas Roloff, stating that the vitality is expressed as tree growth potential and the ability to regenerate damaged crown. The basis for evaluating the vitality is the architecture of shoots produced in the upper part of the crown. This assessment takes into account not only the current state but also a change in the deformation of shoots that have occurred during the past tens of years (Roloff 1989). Defoliation index has also been given, which is a commonly used criterion to assess the degree of damage to trees and forests. Defoliation expresses the loss of assimilation apparatus of the investigated trees in terms of a tree model that is not influenced by damage factors. On the basis of defoliation and vitality, the synthetic index of damage to trees is computed (Dmyterko et al. 2002). Comparing the vitality and the defoliation assessment applied separately, the synthetic index of damage to trees allows for a more objective assessment of the health of trees and stands (Dmyterko, Bruchwald 2002). It is the most reliable index used for the visual assessment of a tree. Finally, ground and remote sensing measurements have been supplemented by laboratory tests. Ground samples were collected, and remote sensing indices related to shape and built of tree roots were estimated:

- FRT: number of terminations of fine roots.

- TRL: the total length of roots.

- FRL: length of fine roots.

- FRSA: area of fine roots.

A significant positive correlation between the results of laboratory measurements and NDVI is observed, for the investigated area in the range of 34-39 [\%]. The high rate of correlation is due to the fact that the state and number of roots directly affects the quantity and quality of plant biomass produced (Czapski et al. 2014). A large number of endings fine roots positively influence the amount of water and mineral salts transported from the soil to the crown of the tree. In order to verify the reliability of NDVI, its level of correlation with the defoliation was investigated, which is subject to error associated with the subjective assessment of the forester. As expected, this ratio corre- lates negatively with NDVI, that is, its value is around $(-) 25 \%$.

Until now, six photogrammetric missions were performed. Table 2 presents NDVI values computed based on images acquired by multispectral camera.

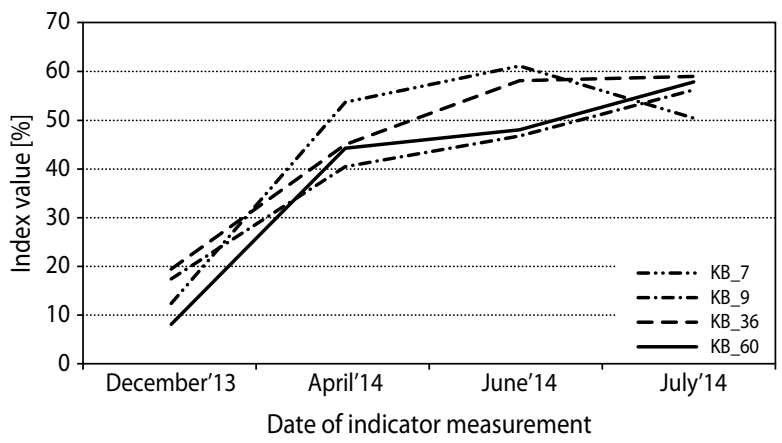

Figure 2a. NDVI values for Karczma Borowa (Leszno) area

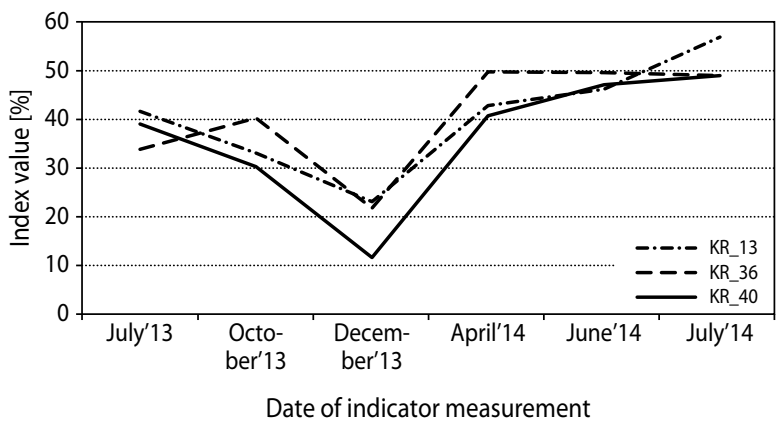

Figure 2b. NDVI values for Krotoszyn area

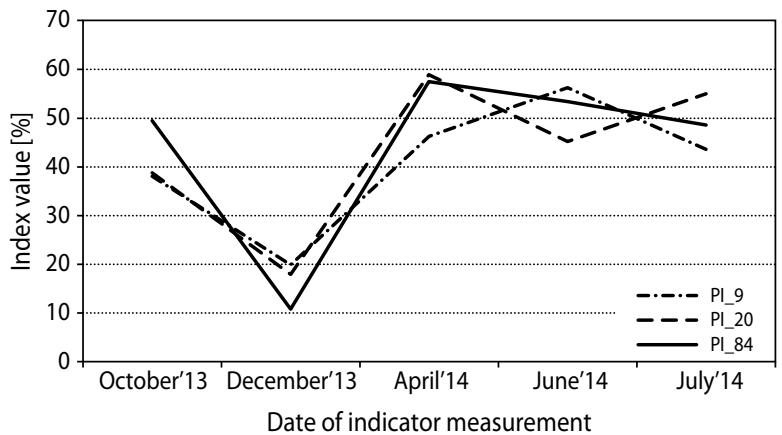

Figure 2c. Piaski area NDVI values

In Figures 2a, 2b and 2c, NDVI variation graphs (few months period) for the selected trees located in three investigated areas are presented. The lowest values are observed in December because of leafless trees' images. The maximum values during the peak of 
growing season, for particular trees in April or May, are observed. Analysis of NDVI showed some indices variation trends for oaks located in the same area of research, and some differences for the three surfaces separated only by a few dozen kilometers. Currently, ongoing work aims to demonstrate the source of such differences.

In addition to the analyses performed with images obtained by UAVs, analysis of satellite images derived from OLI instrument mounted aboard Landsat 8 was carried out. NDVI variability for the area Krotoszyn in April, June and July is shown in Figure 3.

Analysis of images shows a similar trend in changes in NDVI for particular research areas as in the case of data obtained using a non-metric multispectral camera. Nevertheless, using UAV allows maintaining a much higher temporal resolution.

The work showed that multispectral techniques are very useful in forest state evaluation. Visual and geometrical assessment of the crown registered in CIR images indices that the greatest damage occur in experimental areas in Piaski and Krotoszyn forest districts. In Karczma Borowa forest district, crowns are most dense and extensive. Research has shown that the quality and volume of tree crown is closely linked with vegetation indices generated with multispectral photo use. Highest
NDVI value are calculated for Karczma Borowa area. Morphological evaluation of roots showed that amongst examined trees those that were in the Piaski forest district are characterized by the most extensive root systems. The results of laboratory tests are not so highly correlated with multispectral analysis results as visual crown interpretation and crown measurements. This may be due to the fact that nutrient transport mechanisms through the roots and the influence of the roots amount on the plant's development and health is not fully described.

Main results of the research are stored in a geographic information system (GIS). New layers are successively added, and in the near future, soil maps will be added to GIS server. Only a comprehensive analysis of all the indicators and their changes in the growing season allows drawing a valid conclusions on the health of the forest. Currently, results of project conducted in Institute of Aviation allow concluding that indicators derived by remote sensing measurements (aerial photographs) and satellite scenes are correlated with each other and with the indicators collected in situ. The correlation coefficient is around $40 \%$. Long-term monitoring (3 years) in designated areas of research will provide new information on the cycle of oak trees vegetation and will support the process of forest protection.
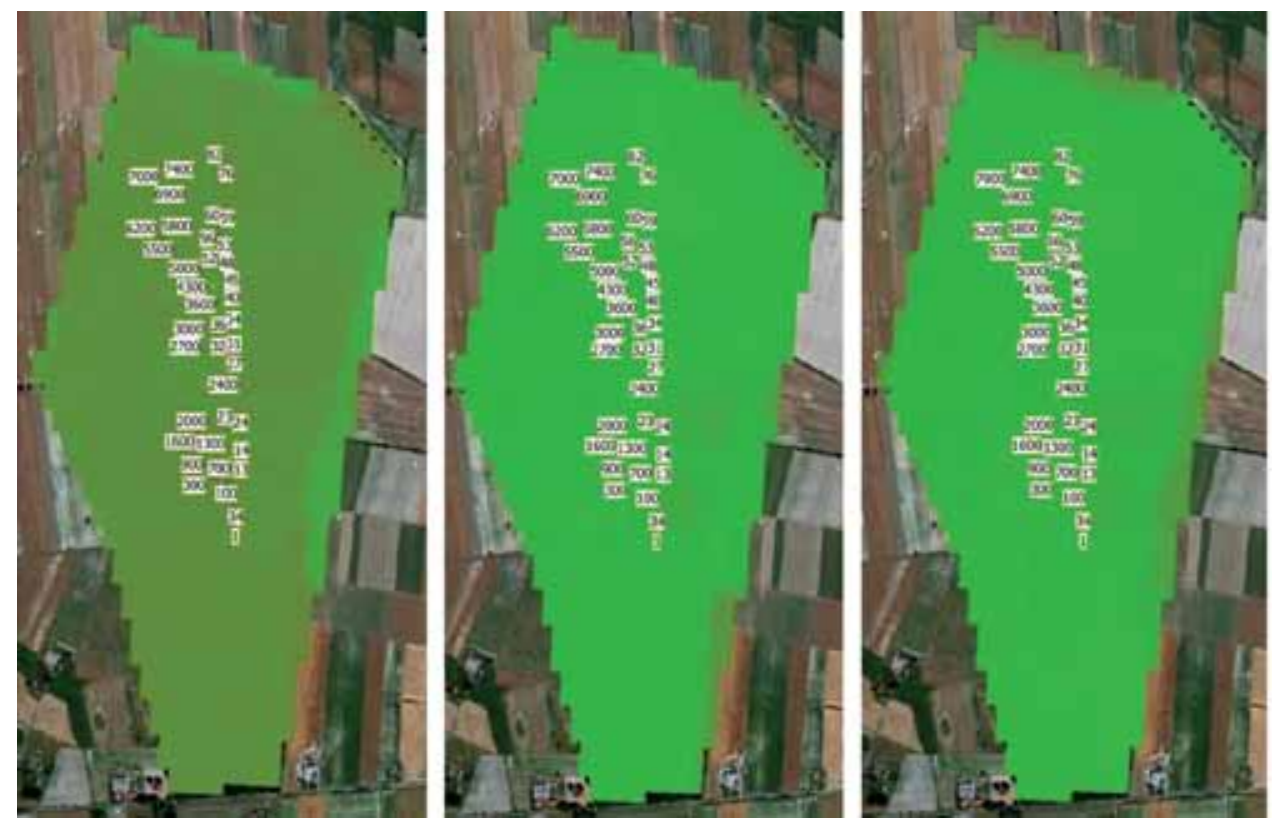

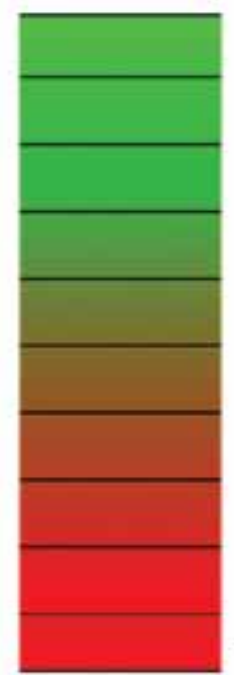

100,0

778

55,6

33,3

11,1

$-11,1$

$-33,3$

$-55,6$

$-77,8$

$-100,0$

Figure 3. NDVI of Krotoszyn area - based on the satellite data (the numbers indicate the test tree) 


\section{Conclusions}

Remotely controlled unmanned systems can be used for immediate image acquisition, miniaturisation of sensors and technology development made it possible to mount cameras working in several spectral bands. Typical matrices of digital cameras with a silicon-based detectors are sensitive to electromagnetic waves in the range of up to $1000 \mathrm{~nm}$ (Holst, Lomheim 2011), and relevant configuration of optical filters allows conducting advanced researches using narrow spectral bands. Application of remotely controlled flying systems is well justified by research that has to be conducted in a small area periodically. In this paper, the methodology of obtaining source data was presented, and associated limitations of non-metric multispectral cameras were addressed. We also have presented means of processing remote sensing data (images) by a software developed in the Remote Sensing Division of Institute of Aviation. Preliminary results of remote sensing measurement indices are quite promising; there is a correlation between in situ measurements and measurements made using satellite scenes and images acquired by a multispectral camera mounted on UAV. Analyses that are conducted periodically, taking into account site characteristics, allow highlighting the adverse changes that may contribute to the gradual plant withering in the absence of corrective action. Multispectral images deliver very valuable information for conducting environmental research; however, their proper interpretation may require experts in the following fields: remote sensing, photogrammetry, GIS, computer science and life sciences.

\section{References}

Bernasik J. 2003. Elementy fotogrametrii i teledetekcji. AGH: Uczelniane Wydawnictwa Naukowo-Techniczne, Kraków.

Białołusz S., Skłodowski P. 1999. Ćwiczenia z gleboznawstwa i ochrony gruntów. Oficyna Wydawnicza Politechniki Warszawskiej, Warszawa.

Ciołkosz A., Białousz S. 2008. Zastosowanie teledetekcji satelitarnej w badaniach środowiska w Polsce. Nauka, 3, 79-96.
Ciołkosz A., Kęsik A. 1989. Teledetekcja satelitana. PWN, Warszawa.

Czapski P., Kacprzak M., Korniluk T., Kotlarz J., Kubiak K., Mazur A., Mrowiec K., Oszako T., Pieniążek J., Pośpieszczyk A., Tkaczyk M., Wodziński K., Zalewska N. 2014. Budowa i zastosowanie platformy wielosensorowej w badaniu wybranych parametrów środowiska. Prace Instytutu Lotnictwa, 1 (234), 126-141.

Dmyterko E., Bruchwald A. 2002. Metody określania uszkodzenia drzewostanów liściastych. Reakcje biologiczne drzew na zanieczyszczenia przemysłowe. Bogucki Wydawnictwo Naukowe, Poznań.

Dmyterko E., Wojtan R., Bruchwald A. 2002. Stan zdrowotny drzewostanów jesionowych (Fraxinus excelsior L.) Nadleśnictwa Mircze. Sylwan, 12, 9-18.

Hardisky M.A., Klemas V., Smart R.M. 1983. The influences of soil salinity, growth form and leaf moisture on the spectral reflectance of Sparina alterniflora canopies. Photogrammetric Engineering and Remote Sensing, 49, 77-84.

Holst G.C., Lomheim T.S. 2011. CMOS/CCD sensors and camera systems. Winter Park, FL: JCD Publishing.

Kurczyński Z. 2006. Lotnicze i satelitarne obrazowanie Ziemi. Oficyna Wydawnicza Politechniki Warszawskiej, Warszawa.

Kurczyński Z. 2014. Fotogrametria. Wydawnictwo Naukowe PWN, Warszawa.

Niedzielko J., Szpietowska M., Boral B., Milczarek M., Pokrzywnicka M., Łach G., Kaźmierczak M., Jarocińska A. 2012. Analiza zależności między zawartością wody $\mathrm{w}$ roślinach zmierzoną $\mathrm{w}$ terenie a teledetekcyjnymi wskaźnikami roślinności. Teledetekcja Środowiska, 47, 43-57.

Osińska-Skotak K. 2007. Znaczenie korekcji radiometrycznej w procesie przetwarzania zdjęć satelitarnych. Archiwum Fotogrametrii, Kartografii i Teledetekcji, 17b, 577-590.

Roloff A. 1989. Kronenentwicklung und Vitalitätsbeurteilung ausgewählter Baumarten der gemässigten Breiten. Schriften aus der Forstlichen Fakultät der Universität Göttingen und Niedersächsischen Forstlichen Versuchsanstalt, Frankfurt am Main. 